\title{
Radical past climatic changes in the Arctic Ocean and a geophysical signature of the Lomonosov Ridge north of Greenland
}

\author{
Naja Mikkelsen, Niels Nørgaard-Pedersen, Yngve Kristoffersen, Susanne Juul Lassen \\ and Emma Sheldon
}

The Arctic Ocean is a landlocked basin, at present covered by perennial sea ice. During the past few decades a significant thinning and shrinking of the sea ice has been observed, and modelling studies indicate that the Arctic Ocean ice cover could, by the end of this century, almost disappear from most parts of the Arctic Ocean during peak summer seasons. It remains uncertain, however, whether the environmental changes are an enhanced greenhouse-warming signal or a result of natural (long-term) variability, but palaeoceanographic studies can contribute to our understanding of the natural variability of environmental parameters, e.g. sea-ice cover and oceanographic changes on time-scales of centuries to millennia.

As part of the multidisciplinary EU project Greenland Arctic Shelf Ice and Climate Experiment (GreenICE), sediment coring and seismic reflection measurements have been undertaken in a hitherto unexplored part of the Arctic Ocean, the margin of the Lomonosov Ridge in the Lincoln Sea (Fig. 1). The aim of the project was to study the structure and dynamics of the sea-ice cover and attempt to relate these to longer-term records of climate variability retrieved from sediment cores. The main field work was carried out in May 2004 from an ice camp established by a Twin Otter aircraft on drifting sea ice at $85^{\circ} \mathrm{N}, 65^{\circ} \mathrm{W}$, c. $170 \mathrm{~km}$ north of Alert, Arctic Canada. The camp was deployed over the shallowest part of the Lomonosov Ridge off the northern Greenland/Canada continental margin (Fig. 1). The sea-ice drift would normally be between east and south, but persistent easterly winds resulted in a fast drift trajectory towards the WSW, such that the camp drifted a distance of approximately $62 \mathrm{~km}$ during the two weeks camp period.

At present the study area is heavily ice covered, and forecast models of future shrinking Arctic sea-ice cover suggest that this area is one of the least sensitive to warming in the Arctic. The results obtained from the GreenICE project challenge this view.

\section{An unexplored area}

The reduction and thinning of Arctic sea ice in recent decades (e.g. Rothrock et al. 1999; ACIA 2004) has drawn attention to whether these environmental changes are an early reaction to global warming, or whether they are part of a long-term variation of the Arctic environment. Modelling studies of global warming effects indicate that the Arctic is
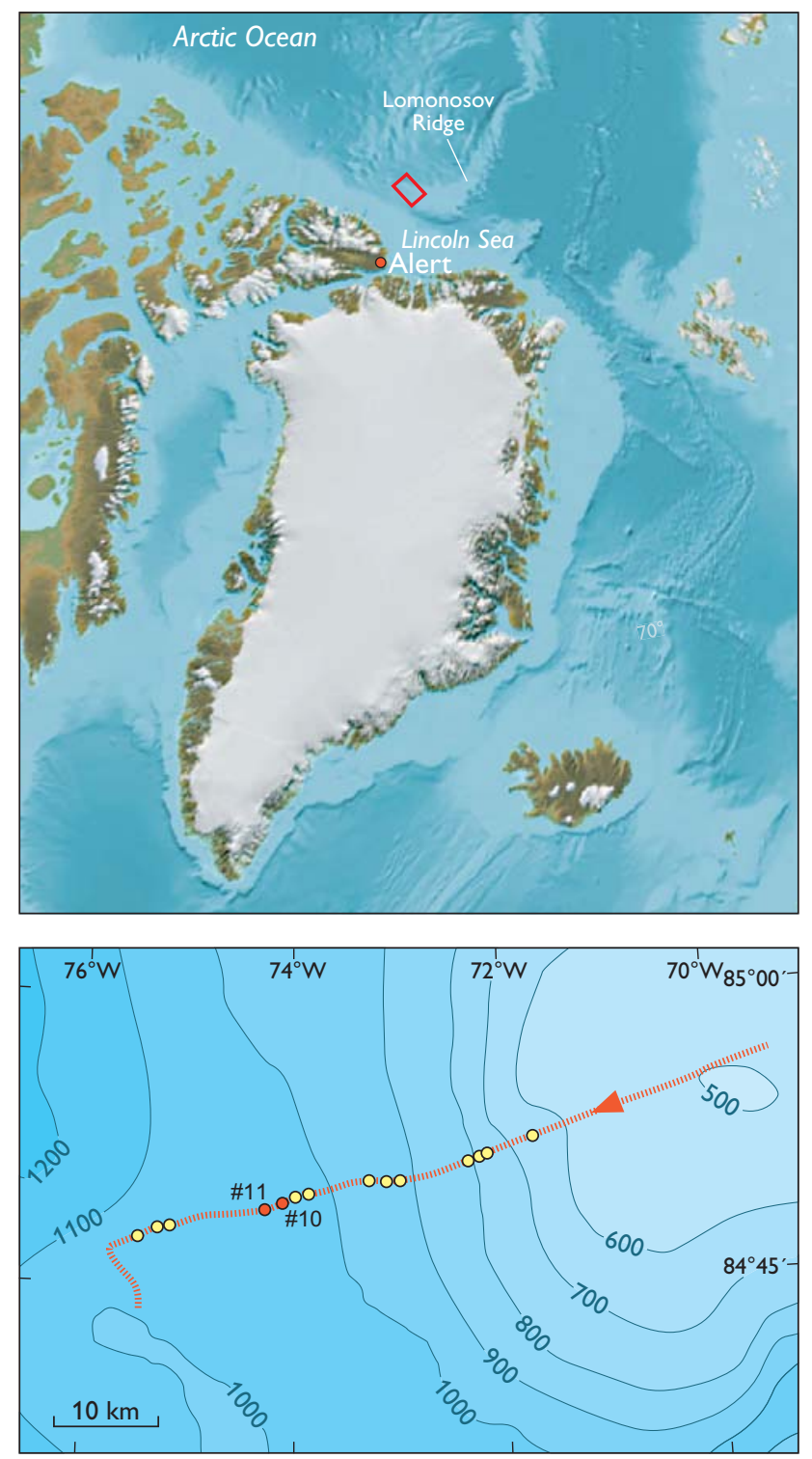

Fig. 1. Upper: The GreenICE field camp area (marked by a red square) was deployed north of Arctic Canada and North Greenland at the shallowest part of the submarine Lomonosov Ridge, in a region where no geologic record has hitherto been retrieved. Lower: Drift path of the field camp is shown by arrow and red line and coring stations by yellow and red dots. 
likely to show a significant temperature increase, and that sea-ice cover could, by the end of this century, almost disappear during peak summer seasons (Johannessen et al. 2004). Such a scenario would not only have a dramatic impact on Arctic ecosystems, navigation and indigenous people, but could also influence the thermohaline circulation and regional climate in the sub-Arctic and North Atlantic region. In a discussion of these scenarios, there is an urgent need for high-latitude Arctic records of variations in climate, oceanography and sea-ice cover representing long time periods and, in particular, records of natural environmental change during earlier warm periods, which can be used to evaluate presentday changes. In spite of its importance, the recent geological record of many parts of the Arctic Ocean, including the Lincoln Sea, are still poorly known and hampered by difficult access.

\section{Reduced ice cover during interglacial periods}

Seismic data and sediment cores were collected from the drifting GreenICE station in this normally inaccessible area of the Lincoln Sea. During the camp period, 15 gravity core stations were established (Figs 1,2), and the retrieved cores were subsequently subjected to a wide array of investigations including AMS $-{ }^{14} \mathrm{C}$ dating, faunal analysis of nannofossils and benthic and planktonic foraminifers, and stable isotope and geochemical analysis. The two longest cores, GreenICE Core $10(176 \mathrm{~cm})$ and GreenICE Core $11(64 \mathrm{~cm})$, show several characteristic colour cycles previously recorded in other parts of the Arctic Ocean (Fig. 3; Phillips \& Grantz 1997; Nørgaard-Pedersen et al. 1998; Jakobsson et al. 2000; Polyak et al. 2004; Spielhagen et al. 2004). The stratigraphy of Core 11 is based on nannoplankton, benthic foraminiferal assem-

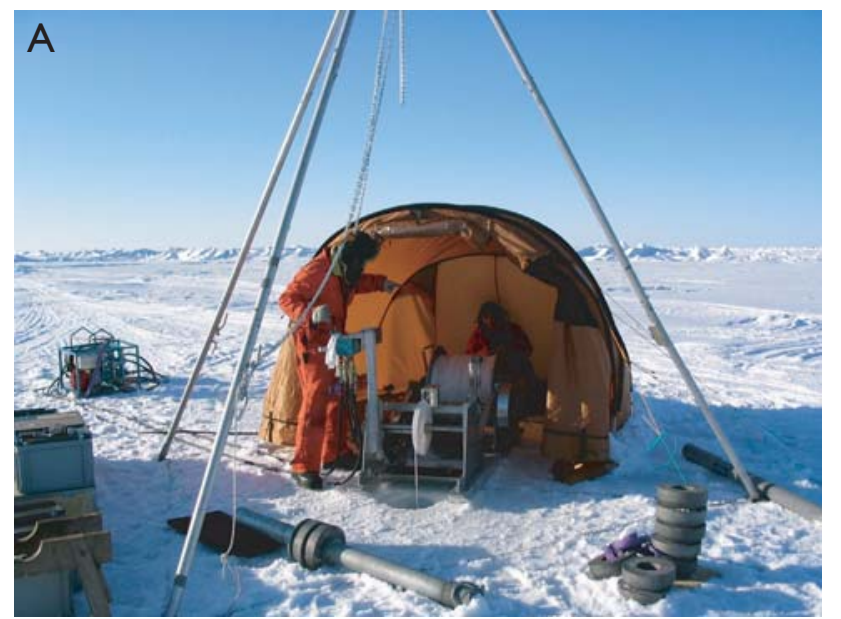

blages and AMS $-{ }^{14} \mathrm{C}$ dates and provides a record of the last $c$. 130000 years, including the last interglacial period (Eemian). Preliminary investigations indicate that the longer Core 10 contains a record of the last c. 200000 years.

Planktonic foraminiferal assemblages are used as a key palaeoceanographic proxy, and a surprisingly large variability of these foraminifers was observed for an interior Arctic Ocean site. The discovery of abundant numbers of the small subpolar foraminifers Turborotalita quinqueloba in two core sections, corresponding to the last interglacial and a younger warm interstadial (Fig. 3), is an enigma, as this species indicates fairly strong subsurface Atlantic water advection and possibly a much reduced summer sea-ice cover in the area compared to present-day conditions. The youngest part of the retrieved sediment record is condensed, but samples taken from close to the surface, representing Holocene and Recent conditions, lack the subpolar foraminifer species and thus indicate a consistent thick perennial sea-ice cover in accordance with present-day conditions (Nørgaard-Pedersen et al. in press)

The results support the concept that interglacial conditions in the interior Arctic Ocean can vary considerably. At present, however, it is not known whether the influx of subpolar foraminifers was related to an ice-margin or polynyatype setting, or whether it reflects a generally reduced sea-ice cover of the interior Arctic Ocean. Ongoing work aims to explore whether the observed trends can be traced to other key sites in the Arctic Ocean.

\section{Seismic investigations and active faulting}

A $62 \mathrm{~km}$ long seismic reflection profile was collected during the drift of the GreenICE field camp (Figs 1, 4). Seismic reflection data were obtained from the shallowest part of the

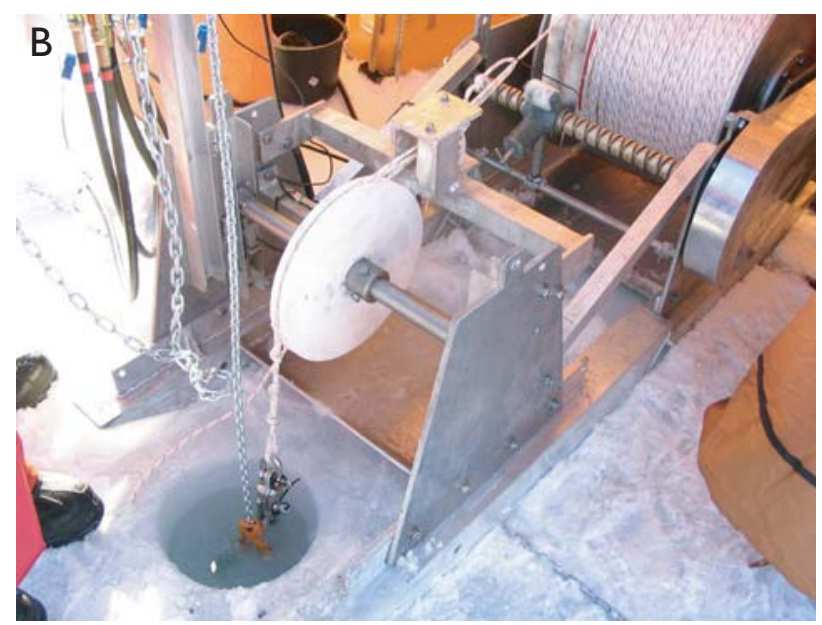

Fig. 2. A: Lightweight gravity coring equipment (constructed by J. Boserup, GEUS) used during the drift of the GreenICE camp. B: Sediment cores were retrieved through a hole drilled in the ice. 


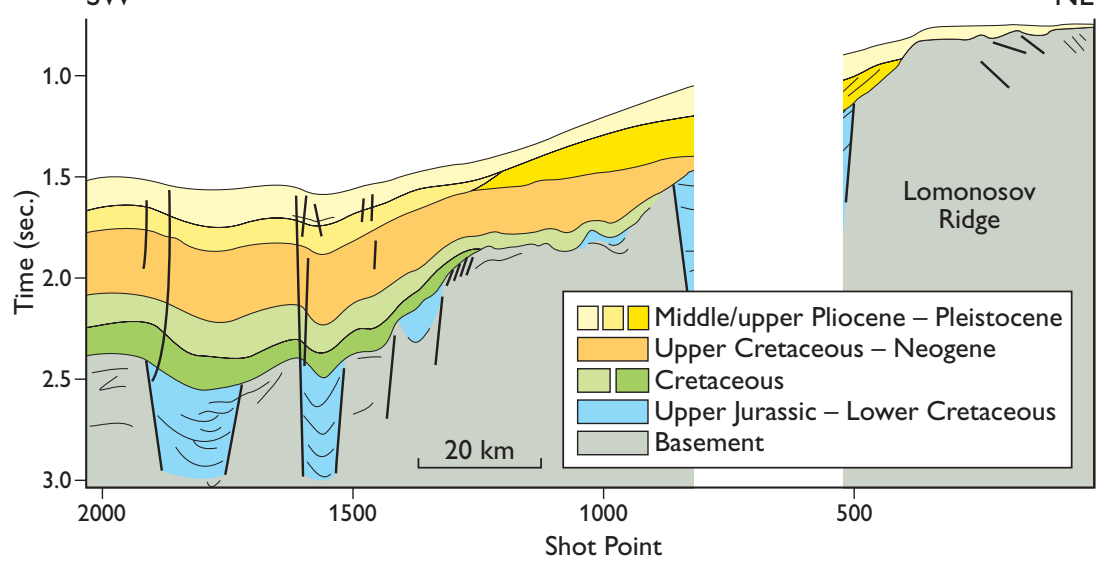

submarine Lomonosov Ridge facing the Canadian/Greenlandic continental margin, and comprise two parallel single channel lines (Kristoffersen \& Mikkelsen 2006). The data reveal that the top of Lomonosov Ridge is bevelled at a water depth of $550 \mathrm{~m}$ and that only a thin sediment cover (less that $50 \mathrm{~m}$ ) overlies the acoustic basement. Pre-Pleistocene sedi- ments were probably eroded by a grounded marine ice sheet extending north from Ellesmere Island, and/or by deep draft icebergs. In the deep passage between the Lomonosov Ridge and the Lincoln Sea continental margin, more than $1 \mathrm{~km}$ of sediment is present. The uppermost $300 \mathrm{~m}$ of this succession reflects a significant sediment drift possibly related to

\section{Core 11}

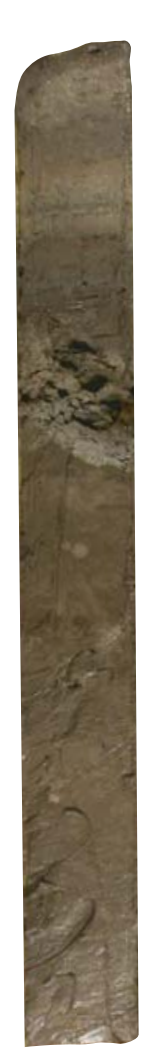

Planktonic foraminifers nos/g sediment

\section{N. pachyderma (sin.)}

$\%$
T. quinqueloba nos/g sediment
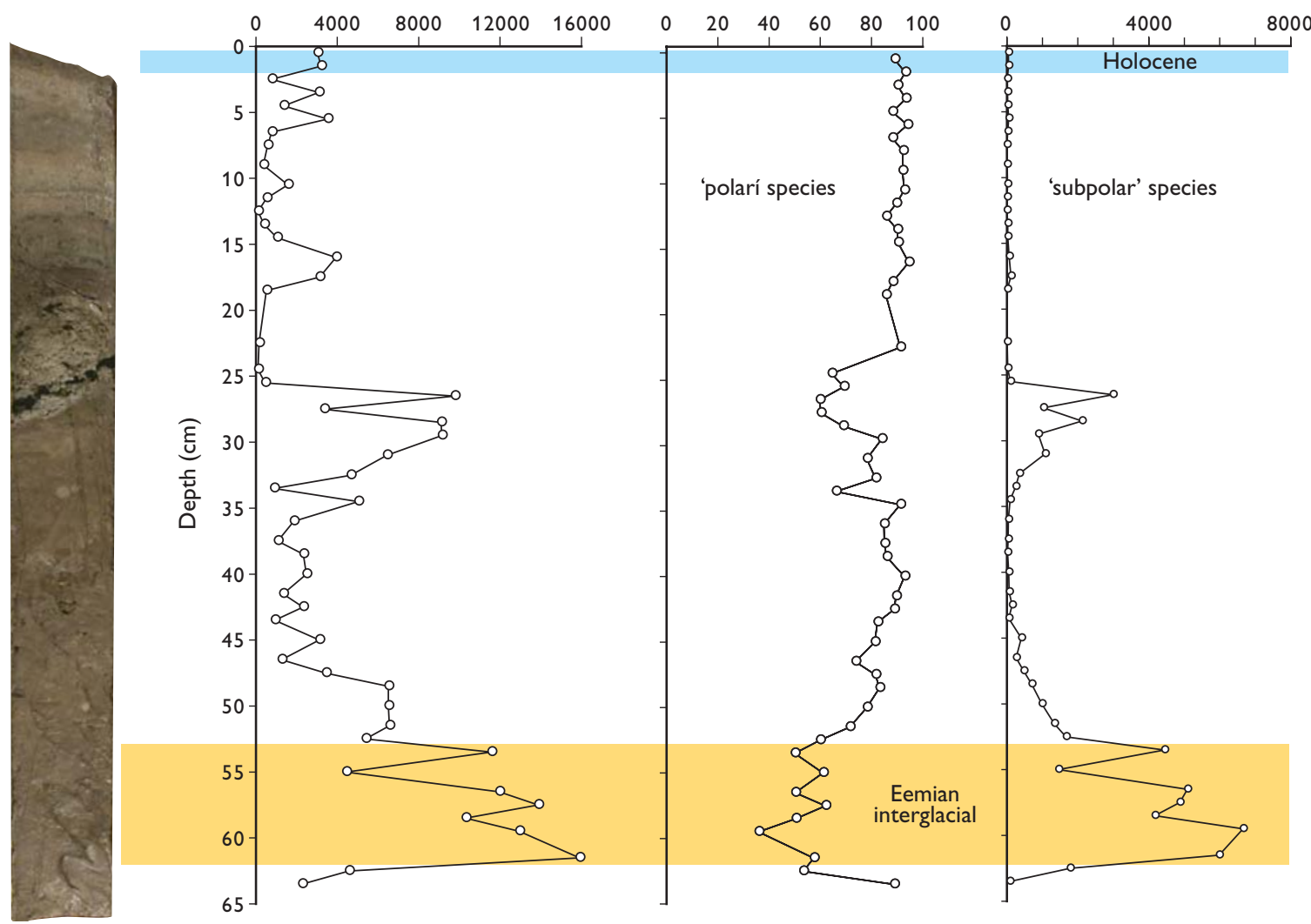

Fig. 3. The GreenICE sediment cores show marked colour cycles. GreenICE Core 11 covers a time span of $c .130000$ years and includes the Eemian interglacial marine isotope stage 5e. Abundant subpolar foraminifers (Turborotalita quinqueloba) in Eemian deposits indicate open water conditions not far from the GreenICE site. This is in contrast to Holocene sediments that show a total dominance of polar species (Neogloboquadrina pachydermal). 
increased Plio-Pleistocene sediment input, and the underlying $700 \mathrm{~m}$ of sediment onlap a subsiding ridge slope. Blocks of older margin sediments may represent the acoustic basement in the area. A basal unconformity, which may correspond to the Hauterivian break-up unconformity of Embry \& Dixon (1994), caps a series of NW-SE-trending grabens, and several of the main graben faults extend to the sea bed and appear to have been active until recent times.

\section{Acknowledgements}

The Greenland Arctic Shelf Ice and Climate Experiment (GreenICE) was supported by EU-grant EVK2-2001-00280.

\section{References}

ACIA, 2004: Impacts of a warming Arctic - arctic climate impact assessment, 144 pp. Cambridge: Cambridge University Press.

Embry, A.F. \& Dixon, J. 1994: The age of the Amerasian Basin. In: Thurston, D.K. \& Fujita, K. (eds): 1992 Proceedings, International Conference on Arctic Margins, 289-294. Anchorage, Alaska, USA: U.

S. Department of the Interior, Minerals Management Service.

Jakobsson, M., Løvlie, R., Al-Hanbali, H., Arnold, E., Backman, J.\& Mörth, M. 2000: Manganese and color cycles in Arctic Ocean sediments constrain Pleistocene chronology. Geology 28, 23-26.
Johannessen, O.M. et al. 2004: Arctic climate change: observed and modelled temperature and sea-ice variability. Tellus A 56, 559-560.

Kristoffersen, Y. \& Mikkelsen, N. 2006: On sediment deposition and nature of the plate boundary at the junction between the submarine Lomonosov Ridge, Arctic Ocean and the continental margin of Arctic Canada /North Greenland. Marine Geology 225, 265-278.

Nørgaard-Pedersen, N., Spielhagen, R.F., Thiede, J. \& Kassens, H. 1998: Central Arctic surface ocean environment during the past 80,000 years. Paleoceanography 13, 193-204.

Nørgaard-Pedersen. N., Mikkelsen, N., Lassen, S.J., Kristoffersen, Y. \& Sheldon, E. in press: Arctic Ocean sediment cores off northern Greenland reveal reduced sea-ice concentrations during the last interglacial period. Paleoceanography.

Phillips, R.L. \& Grantz, A. 1997: Quaternary history of sea ice and paleoclimate in the Amerasia basin, Arctic Ocean, as recorded in the cyclical strata of Northwind Ridge. Geological Society of America Bulletin 109, 1101-1115.

Polyak, L., Curry, W.B., Darby, D.A., Bischof, J. \& Cronin, T.M. 2004: Contrasting glacial/interglacial regimes in the western Arctic Ocean as exemplified by a sedimentary record from the Mendeleev Ridge. Palaeogeography, Palaeoclimatology, Palaeoecology 20, 73-93.

Rothrock, D.A., Yu, Y. \& Maykut, G.A. 1999: Thinning of the Arctic seaice cover. Geophysical Research Letters 26, 3469-3472.

Spielhagen, R.F., Baumann, K.-H., Erlenkeuser, H., Nowaczyk, N.R., Nørgaard-Pedersen, N., Vogt, C. \& Weiel, D. 2004: Arctic Ocean deepsea record of northern Eurasian ice sheet history. Quaternary Science Reviews 23, 1455-1483. 